\title{
Mutual Relationship of Wine Industry vs. Wine Tourism: The Israeli Perspective
}

\author{
Nathan Tirosh \\ The Kinneret College on the Sea of Galilee, Emek Hayarden, Israel
}

\begin{abstract}
Wine tourism is identified as a symbolic partner of the wine industry. The wine industry in Israel has been experiencing a rapid development from a small wine producer for the Jewish community to a substantial wine industry which exports a wide variety of top-quality wines, which is followed by wine tourism activities. The objective of the research is to determine the perceived strategy of wine stakeholders in relation to the wine tourism, and to indicate future implications. The research applies the tourism area life cycle (TALC) model and the SWOTCLOCK ${ }^{\mathrm{TM}}$ approach. Results show that the "leading strategy" of big commercial wineries is growth compared to the response strategy of small and family wineries and survival of mid wineries. Government ministries and the Vine and Wine Board (VWB) perceive leverage to be the "leading strategy". Findings of empirical data analysis position the current leading strategy as response and prove the validation between the TALC and SWOTCLOCK ${ }^{\mathrm{TM}}$ models. The key conclusion and recommendation is that government ministries, VWB, and local authorities should take a leading role in leading the wine industry and tourism sector towards the rejuvenation and growth stage.
\end{abstract}

Keywords: wineries, SWOTCLOCK ${ }^{\mathrm{TM}}$, tourism area life cycle (TALC), growth, response, survival, leverage, leading strategy

\section{Introduction}

Wine was mentioned in the Bible when Moses sent two Israelite spies to explore the land of Israel who "cut down from thence a branch with one cluster of grapes and they bare it between two upon a staff" (Numbers XIII, 23), followed by the prophet Micah with his vision that, "They shall sit every man under his vine...” (Micah IV, 4). Producing wine in Israel reached its peak during the Second Temple, but later on was stopped when the Romans destroyed the Temple and the Jews were sent into exile. The wine industry was totally wiped out during the period of the Ottoman until the World War I. In the 19th century, there are a few and small isolated wineries operated in Israel, and in 1848, the first commercial winery was established by the Baron Edmond de Rothschild who gave sponsorship and financial support for wine production, and imported varieties of vines from Bordeaux in southern France, as well as technical support of professional winemakers. The development of the wine industry received a significant boost in the 1980s, when Professor Cornelius of the University of California claimed that the Golan Heights area was suited for growing grapes of excellent quality. Robinson (2006) noted that according to the International Organization of Vine and Wine (OIV), the area covered by vineyards in Israel in 2003 was approximately 17,000 acres, producing some 57,000 hectoliters

Nathan Tirosh, lecturer of Management and Strategy Formulation, and Marketing and Tourism, Department of Tourism and Hotel Management, The Kinneret College on the Sea of Galilee. Email: ntirosh@galilcol.ac.il. 
of a large selection of high-quality wines, part of which were exported. Subsequently, Israeli wineries began to participate in international competitions and have won numerous awards and accolades for quality wines. A commitment to high quality and presentation of a variety of new wines have changed the culture and consumption, brought about the establishment of new vineyards and professionalism in producing wine, and led to the construction of about 200 new wineries, mostly small and family (boutique) wineries. There are five official wine zones: Galilee \& Golan Heights, the Shomron (Carmel Mountain), Samson, the Judean Hills and the Jerusalem mountains, and the Negev. There is no formal system of wineries registration in Israel and the general estimate is that approximately 250-300 wineries are currently operating in the wine sector. Although accurate and viable data are difficult to gather (Shor \& Mansfeld, 2009), according to Vine and Wine Board (VWB) and the Ministry of Agriculture, planted vineyard area by 2012 covered about 55,000 dunams ( 1 acre $=10$ dunams), yielding approximately 55,000 tons of grapes (Harkabi, 2012) and enabling the production of close to 45 million bottles. The implementation of the Pareto rule groups wineries into three major groups: seven big wineries with clear commercial orientation (above 2.5 million bottles and about $80 \%$ market share), 15-20 mid wineries, producing 120,000-1,000,000 bottles (about 12\% market share), and the small and family (boutique) wineries (production of up to 100,000 bottles a year). The establishment of new vineyards and planting new types of grapes at an increased rate was followed by a growing wine culture and changing consumption habits in relation to wine. Visitor centers, cellar doors, and quality restaurants started offering wine as part of the gastronomic experience; wine tasting competitions started appearing, as well as festivals and early initiatives of "wine route". Although the Israeli wine sector has experienced an impressive development over the last two decades, the wine consumptions per person are estimated to stand steadily at 5.5 liters per person per year, far behind 65-70 liters per person per year in France. This, together with the growth in wine supply beyond the demand of the local current market, import competition, and the beginning of wine export, sets tremendous challenge to the wine sector.

\section{Literature Review}

For thousands of years, wine accompanied by the development of human society as one of the components which compliment to the food served has been used to inspire joy and pleasure. Wine as a consumer product begins its supply chain at the initial step of growing grapes as raw material, continues to the second stage of wine production, and finishes as one of the vertebrae in the distribution and marketing to leverage the product to the end consumer. Mora (2007) indicated that for many years, the traditional wine center both production and tourism was located mainly in European countries such as Italy, France, Spain, and Portugal ("Old Wine World”). Substantial development in wine tourism, which accompanies the development of new and attracts young people, can be seen in the US, Australia, and New Zealand ("New Wine World”). South Africa's famous wine culture and industry developed at a slower pace, mainly for political reasons. Over the last two decades, there have been more and more research activities related to the wine industry, combined with wine tourism, as the conspicuous phenomenon of focusing on specific areas. Getz (2000) and Hall, Sharples, Cambourne, and Macionis (2000) were among the first who contributed to a deeper understanding of the characteristics of wine tourism. Hall et al. (2000) defined wine tourism as "visitation to vineyards, wineries, wine festivals, and wine shows for which grape tasting and/or experiencing the attributes of a grape wine region are the prime motivating factors for visitors". In order to enrich the visit in the region, the visit has to include some unique quality as defined by the Winemakers' Federation of Australia (1998): "visitation to wineries and wine regions 
to experience the unique qualities of contemporary Australian lifestyle associated with enjoyment of wine at its source-including wine and food, landscape, and cultural activities” (Carlsen, 2004, p. 6). In line with this definition, Getz, Dowling, Carlsen, and Anderson (1999), Getz (2002), Sparks and Malady (2004), and Sanders (2004) undertook some more studies on the characteristics of wine tourism. Carlsen and Charters (2006) suggested that wine tourism is based upon six major areas: wine tourism setting, regional development, wine marketing and tourism, cellar doors, wine festivals and events, and wine tours and trails. In spite of the fact that wine tourism contributes to the increase in wine consumption and that both of them complement one another, Carlsen (2004) suggested that it is important to recognize that the wine industry and wine tourism are positioned opposite each another in the industrial micro-cosmos spectrum. The conclusion is that much more work should be done in order to understand how wine industry and wine tourism both diverge and also converge through the application of a wide range of economic, culture, geographic, and other related factors. This is a fundamental issue for further research and investigation. Shor and Mansfeld (2009) investigated the characteristics of Israeli wine tourists in terms of their lifestyle attributes and wine-related behavior. The findings of the research show that wine tasting is the main motivation for visiting wine tourism sites, especially wineries, where the level of interest was higher than knowledge about wine and its production process. Cohen and Ben-Nun (2009) analyzed the salient features of wineries from the perspective of potential Israeli visitors which enable operators to develop varied wine tourism products. Findings indicate that different segments yielded different importance ratings and that motivation of choosing a wine region as a tourism destination goes beyond a simple desire to experience wine. Getz (2000) indicated that wine tourism consists of three major components: wine producers, tourism operators, and consumers. As a consequence, wine tourism provides marketing opportunity for wineries to teach and educate wine and potential customers and at the same time to their products, particularly to wine lovers or those who are interested in visiting preferred destinations (Getz \& Brown, 2006; Charters \& Ali-Knight, 2002). Getz, Carlsen, Brown, and Havitz (2007, p. 246) indicated that, "Wine tourism is a special interest travel based on the desire to visit wine producing regions...", and extended the connection between wine industry and wine tourism. Understanding the life style of wine tourists and wine tourism experience can also improve wine marketability and profitability for wineries and other partners in the wine production area. Dowling and Getz (2001) indicated that both the supply of wineries and consumer behavior demand should be taken into account. The concept of synergy of wine manufacturers and wine tourism elements can lead to economic growth, particularly at "new world" wine destinations, such as Napa Valley (USA) and Margaret Valley (Australia). To achieve this, the wine tourism council, in collaboration with wine industry and political stakeholders, should be the leading bodies in the development and marketing of wine tourism through the provision of the necessary infrastructure throughout the wine region. Cambourne, Macionis, Hall, and Sharples (2002) indicated that wine tourism is an emerging broad scope of interest associated with future potential of the wine tourism and industry at regional, national, and international levels. In that line, they indicated that some wineries in Napa Valley have already started meeting the demand by supplementing wine tasting with wine education. Issues influencing future wine tourism and wine industry development are mainly: securing initial funding and regional financial commitments to wine routes development (Europe); loss of agricultural land to urbanization development (Canada) and access to land (South Africa); a lack of constant relevant information and data about impact of wine tourism associated with wine industry (Canada/UK); ensuring that wineries see a tangible return on investment (ROI), which affects wine industry and tourism willingness to invest in product development initiatives (Australia); the 
unwillingness of the wine industry to commit resources to tourism participation (USA); and difficulties in establishing a joint network for the wine and tourism sectors. Skinner (2002) indicated that there are some limits to wine tourism development, which requires detailed studies of elements within and around a wine region. This calls for a careful planning which incorporates all interested parties including local, regional authorities and government, vintners, wineries and wine tourism operators, and most especially, the local residents. It is recommended that smaller wineries should be regulated as closely as any larger corporation. A good example of this is the wine route development in the Bairrada region of Portugal. Correira and Ascencao (2006) indicated the necessary steps of the process in the process of developing a wine route, which enables visitors to meet wine producers. Bras, Costa, and Buhalis (2010) emphasized that after some previous failures to promote the development of the Bairrada wine route (BWR), it is important to involve a large number of economic partners and to gather public and political support, by organizing first-step actions and increasing network trust and communication. Sacks and Goldfisher (2011) suggested that wine tourism and in particularly wine route development should take into consideration visiting not only wine production sites but also historic and archeologist sites in order to enrich the wine travel experience. A dichotomous situation was highlighted by Fraser and Alonso (2006), who clearly indicated that wine tourism may present significant downside aspects to the business of making and marketing wine. In their research, it was very clearly indicated by some winery owners that the alleged benefits of wine tourism were insufficient to encourage them to engage in this operation. It clearly appeared that not every grower is willing to commit himself/herself and to get deeply involved in wine tourism. The literature review highlights the fact that wine tourism research concentrates mainly on the characteristics of the wine tourist and on wine travel behavior rather than on the wine manufacturer's perspective in relation to his/her business environment characteristics. Currently, the Israeli wine industry and tourism sector is faced with the dilemma of how to move forward. This emphasizes the need to further study and investigate wineries policy, wine tourism, and officials and regulators such as the Ministry of Agriculture, Israeli Land Authority (ILA), etc., concerning the future steps and strategy which will lead the sector towards growth and prosperity.

\section{Research Methodology and Approach}

In light of the literature review, it is clear that the wine sector embeds both wine production and wine tourism. Intense development has taken place in Israel in the last decade that may lead the sector to reappraise its strategy, with the overall objective of increasing wine consumption. This has yielded the following research question: "What is the leading strategy of the wine sector, given the relationship between the wine industry and wine tourism, and what are the implications for the future?”. The hypothesis assumes that there is a difference in the "leading strategy" of various stakeholder groups which reflects their perception as to the strategic position of the wine sector. The study applies the SWOTCLOCK ${ }^{\mathrm{TM}}$ (Tirosh, 2010; 2013) and the tourism area life cycle (TALC) (Butler, 2006a; 2006b) models. The research operated visits to wineries in all winery zones, as well as in-depth interviews with winery owners, people at the Ministry of Tourism, the Ministry of Agriculture, VWB, and other stakeholders who are involved in the wine sector. Questionnaires were processed using the SPSS program for significance (one-way analysis of variance (ANOVA), $t$-test). Stakeholders were segmented into five groups: government ministries and VWB, big, mid, small and family wineries, and independent stakeholders (wine consultants, etc.). The sample size of 56 valid questionnaires as to the wineries groups' segmentation proportion is shown in Table 1 below. 
Table 1

Segmentation of Research Sample Groups

\begin{tabular}{lc}
\hline Sample group & Size \\
\hline Government ministries and VWB & 6 \\
Big-size wineries (> 1,000,000 bottles) & 6 \\
Mid-size wineries (100,000-1,000,000 bottles) & 9 \\
Small- and family-size wineries (10,000-100,000 bottles) & 31 \\
Other (independent consultants, etc.) & 4 \\
Total & 56 \\
\hline
\end{tabular}

Some wineries which were approached did not participate in the research, stating personal reasons and reservations, resistance to exposing business data, etc.. Empirical data concerning the trends of vineyards' new plantation had been collected. A regression analysis was applied to test the validity and compliance significance between the "leading strategy" determined by the SWOTCLOCK ${ }^{\mathrm{TM}}$ model and related characteristics of the TALC model.

\section{Research Findings and Discussion}

\section{Determination of the Mutual "Leading Strategy” of Wine Stakeholder Groups}

The research methodology used is the SWOTCLOCK ${ }^{\mathrm{TM}}$ approach (Tirosh, 2010; 2013). The leading strategy derived from the SWOTCLOCK ${ }^{\mathrm{TM}}$ model reflects an "equivalent vector" determined by the relative "power intensity" of four vectors: strengths $(\mathrm{S})$ and weaknesses $(\mathrm{W})$ as internal vectors and opportunities (O) and threats (T) as external vectors. Bernroider (2002) indicated that the list of the external and internal factors is subjectively determined with reference and prior review. Factors in the questionnaire (Bernroider, 2002) are partly derived from the components indicated in the literature review, while others came from the preliminary visits and interviews held at the wineries. "Level of importance" (weighted factor) and "strategic position" operate as two independent variables in the calculation procedure of each of the "power intensity" of the four strategic vectors $\mathrm{S}, \mathrm{W}, \mathrm{O}$, and $\mathrm{T}$.

The "level of importance" scores for each group factor should be $100 \%$. Results of the average "level of importance" (weighted factors) are shown in Table 2: For the internal factors group, scores for the "wine sector" show that "wine know-how and technology" $(12.9 \%)$ and "wine culture" (12.9\%) are highly important for the sector, followed by "visitor center facilities" (12.2\%), whereas the "availability of database" factor is the least important (4.4\%). Results of the ANOVA analysis show significant results $(p<0.05)$ for the "wine equipment and facilities" factor, between government and VWB, big wineries, and small and family wineries, for the "wine know-how and technology" factor between government and VWB, big wineries, and small and family wineries, and for "wine pricing" factor between government and VWB and all wineries. Big wineries group rates the "wine culture" factor at a lower level than other wineries groups. In addition, the "winery equipment and facilities" and "wine know-how and technology" factors are more important to big wineries than to other groups.

For the external factors group, scores for the "wine sector" show that the "wine market demand" factor (13.6\%) is the main concern of all groups, followed by "wine trail and tourism development" (12.7\%) and "economy, security, and ecology" factor (10.9\%). Least important is the "HR availability" (4.7\%) factor. Regarding the "regulations and standards" factor, the government and VWB (12.8\%) and other group (11.7\%) rate this factor higher than the winery groups. The "strategic position" (currently) is determined along a Likert type scale. Calculated results of the current strategic position (average) are listed in Table 3. 
Table 2

Internal and External Weighted Factors (\%) by Stakeholder Groups

\begin{tabular}{|c|c|c|c|c|c|c|c|}
\hline Category & Factor & $\begin{array}{l}\text { Government } \\
\text { and VWB }\end{array}$ & $\begin{array}{l}\text { Big } \\
\text { wineries }\end{array}$ & $\begin{array}{l}\text { Mid } \\
\text { wineries }\end{array}$ & $\begin{array}{l}\text { Small and } \\
\text { family } \\
\text { wineries }\end{array}$ & Other & Wine sector \\
\hline \multirow{12}{*}{$\begin{array}{l}\text { Internal } \\
\text { factors }\end{array}$} & Winery equipment and facilities & 4.3 & 12.0 & 8.0 & 11.1 & 8.3 & 9.8 \\
\hline & Wine know-how and technology & 7.0 & 14.6 & 11.1 & 14.5 & 10.0 & 12.9 \\
\hline & Wine basket variety & 3.0 & 7.6 & 5.2 & 5.2 & 4.3 & 5.2 \\
\hline & Wine region and terroir & 6.5 & 11.4 & 12.3 & 12.4 & 10.8 & 11.7 \\
\hline & Wine standard & 4.8 & 9.4 & 8.2 & 7.2 & 14.7 & 7.9 \\
\hline & Wine pricing & 21.7 & 6.4 & 10.2 & 6.0 & 8.3 & 8.4 \\
\hline & Visitor center facilities & 13.2 & 10.4 & 11.8 & 12.4 & 12.3 & 12.2 \\
\hline & Visitor center quality of service & 11.5 & 10.4 & 8.5 & 9.3 & 5.3 & 9.2 \\
\hline & Wine tourism product variety & 7.8 & 6.0 & 5.3 & 5.1 & 6.0 & 5.4 \\
\hline & Availability of database & 4.0 & 3.0 & 6.1 & 4.0 & 5.0 & 4.4 \\
\hline & Wine culture & 16.2 & 8.8 & 13.3 & 12.8 & 15.0 & 12.9 \\
\hline & Total (\%) & 100.0 & 100.0 & 100.0 & 100.0 & 100.0 & 100.0 \\
\hline \multirow{12}{*}{$\begin{array}{l}\text { External } \\
\text { factors }\end{array}$} & Wine market demand & 18.3 & 18.6 & 12.9 & 9.8 & 7.7 & 13.6 \\
\hline & Ministry of Tourism policy & 6.2 & 8.4 & 10.3 & 9.0 & 7.2 & 9.1 \\
\hline & Ministry of Agriculture policy & 11.7 & 7.5 & 8.1 & 8.5 & 8.3 & 8.1 \\
\hline & VWB policy & 6.3 & 9.4 & 6.9 & 6.5 & 6.8 & 6.8 \\
\hline & Ministry of Industry and Trade & 8.7 & 9.0 & 6.5 & 6.9 & 7.0 & 7.2 \\
\hline & Investors’ willingness & 8.4 & 9.6 & 12.3 & 9.7 & 9.5 & 10.1 \\
\hline & Economy and security & 5.2 & 9.5 & 10.4 & 11.9 & 15.1 & 10.9 \\
\hline & Availability of financial support & 4.3 & 8.5 & 8.2 & 9.4 & 7.8 & 8.2 \\
\hline & Wine trail and tourism development & 13.3 & 10.6 & 12.8 & 13.7 & 15.3 & 12.7 \\
\hline & HR availability & 4.8 & 3.5 & 4.2 & 5.8 & 3.6 & 4.7 \\
\hline & Regulations and standards & 12.8 & 5.4 & 7.4 & 8.8 & 11.7 & 8.6 \\
\hline & Total (\%) & 100.0 & 100.0 & 100.0 & 100.0 & 100.0 & 100.0 \\
\hline
\end{tabular}

For the internal factors group, as shown in Table 3, all stakeholder groups perceive "winery equipment and facilities" (5.1) and "wine know-how and technology" (4.8) as very strong areas of the sector, as opposed to "wine standard" (1.5), "availability of database" (1.0), "wine culture" (2.1), and "wine region and terroir" (2.2) as weak areas of the sector. Significance in difference of opinions among the groups $(p<0.05)$ is found regarding the "wine pricing" factor, between government and VWB, big wineries, and mid wineries groups. In addition to that, big wineries consider the "wine pricing" factor as very strong (4.5), but it drops to 3.3 for mid wineries and 2.5 for small and family wineries. This means that big wineries perceive current pricing level as a point of "strength", but that it is perceived as a "threat" to the small and family wineries. For the "availability of database" factor, a significant difference was found between government and VWB and mid wineries. A significant difference exists regarding the "wine culture" factor, between government and VWB and all wineries groups. For big wineries group, the "wine culture" factor score is 3.2 (slightly strong), but it drops to 2.6 (slightly weak) for mid-size wineries and 2.1 (quite weak) for small and family wineries. This means that small and family wineries seek to increase wine culture, which is an important issue for them, more than for mid and big wineries. Regarding the external factors, "wine trail and tourism development" factor (4.7) is perceived by all stakeholder groups as the biggest opportunity for growth, followed by "HR availability” (3.9). All other external factors' scores are at the break-even position (around 3.0) or below on 
the threats side $(<3.0)$. An interesting result is the significant difference $(p<0.01)$ between the government and VWB and ministry opinion as to their perception of their own policy in relation to the wine sector. They rank the "Ministry of Tourism policy" (4.0), "Ministry of Agriculture policy" (5.5), and "VWB policy" (6.0) as a big opportunity for the wine sector; however, big and mid wineries perceive their attitude as a kind of a "threat" to them and the small and family wineries are indifferent to them (3.0). A significant difference was found concerning "wine market demand" where the government and VWB's perception was that currently, this factor threatens the sector, compared to the other groups which feel that the current wine demand is neither a threat nor an opportunity to the sector.

Table 3

Strategic Position by Stakeholder Groups

\begin{tabular}{|c|c|c|c|c|c|c|c|}
\hline Category & Factor & $\begin{array}{l}\text { Government } \\
\text { and VWB }\end{array}$ & $\begin{array}{l}\text { Big } \\
\text { wineries }\end{array}$ & $\begin{array}{l}\text { Mid } \\
\text { wineries }\end{array}$ & $\begin{array}{l}\text { Small and } \\
\text { family } \\
\text { wineries }\end{array}$ & Other & Wine sector \\
\hline \multirow{11}{*}{$\begin{array}{l}\text { Internal } \\
\text { factors }\end{array}$} & Winery equipment and facilities & 5.8 & 5.5 & 4.8 & 5.1 & 5.7 & 5.1 \\
\hline & Wine know-how and technology & 5.5 & 5.5 & 4.9 & 4.5 & 5.0 & 4.8 \\
\hline & Wine basket variety & 3.8 & 5.0 & 3.7 & 4.3 & 5.0 & 3.9 \\
\hline & Wine region and terroir & 2.3 & 2.5 & 1.2 & 3.2 & 2.0 & 2.2 \\
\hline & Wine standard & 1.0 & 1.2 & 1.3 & 1.7 & 2.3 & 1.5 \\
\hline & Wine pricing & 1.0 & 4.5 & 3.3 & 2.5 & 2.7 & 2.9 \\
\hline & Visitor center facilities & 3.0 & 3.2 & 2.3 & 2.0 & 3.0 & 2.4 \\
\hline & Visitor center quality of service & 3.3 & 4.3 & 4.7 & 3.6 & 3.3 & 3.8 \\
\hline & Wine tourism product variety & 3.8 & 2.2 & 3.0 & 3.2 & 2.3 & 3.1 \\
\hline & Availability of database & 0.5 & 1.3 & 1.6 & 0.7 & 0.7 & 1.0 \\
\hline & Wine culture & 0.5 & 3.2 & 2.6 & 2.1 & 1.7 & 2.1 \\
\hline \multirow{11}{*}{$\begin{array}{l}\text { External } \\
\text { factors }\end{array}$} & Wine market demand & 0.3 & 3.2 & 3.3 & 3.4 & 3.0 & 3.1 \\
\hline & Ministry of Tourism policy & 4.0 & 2.2 & 2.4 & 3.0 & 1.7 & 2.8 \\
\hline & Ministry of Agriculture policy & 5.5 & 2.6 & 2.3 & 3.0 & 3.3 & 3.0 \\
\hline & VWB policy & 6.0 & 3.0 & 2.3 & 3.1 & 4.0 & 3.2 \\
\hline & Ministry of Industry and Trade & 2.0 & 3.2 & 2.1 & 2.3 & 2.7 & 2.3 \\
\hline & Investors’ willingness & 3.8 & 4.0 & 2.9 & 2.6 & 3.3 & 2.8 \\
\hline & Economy and security & 1.8 & 2.4 & 1.9 & 1.6 & 1.0 & 1.7 \\
\hline & Availability of financial support & 2.3 & 3.6 & 2.3 & 2.0 & 3.7 & 2.3 \\
\hline & Wine trail and tourism development & 4.8 & 4.0 & 4.6 & 4.9 & 5.0 & 4.7 \\
\hline & HR availability & 4.8 & 4.4 & 4.2 & 3.4 & 4.7 & 3.9 \\
\hline & Regulations and standards & 1.3 & 2.4 & 2.5 & 2.6 & 0.7 & 2.3 \\
\hline
\end{tabular}

Notes. ${ }^{*}$ : Strength score scale: 4, 5, 6; Weakness score scale: $0,1,2 .{ }^{* *}$ : Opportunity score scale: 4, 5, 6; Threat score scale: $0,1,2$.

The intensity value of each of the SWOTCLOCK ${ }^{\mathrm{TM}}$ vectors $\mathrm{S}, \mathrm{W}, \mathrm{O}$, and $\mathrm{T}$ is calculated as the multiplication of the level of importance score by the current strategic position. The product of the relative weight (100\%) in formation of the indifferent " 3 " score position is: -300 . When the vector value of the internal factors is greater than 300 (positive value), it means that the "organization" is "stronger" than "weaker" and vice versa when it is less than 300 (negative value). When the vector value of the external environment is greater than 300 (positive value), it means that there are more "opportunities" than "threats" and vice versa. Results of the intensity vectors are presented in Table 4. 
Table 4

Internal and External Vector Intensity of Various Groups

\begin{tabular}{|c|c|c|c|c|c|c|c|c|}
\hline Category & Factor & $\begin{array}{l}\text { Government } \\
\text { and VWB }\end{array}$ & $\begin{array}{l}\text { Big } \\
\text { wineries }\end{array}$ & $\begin{array}{l}\text { Mid } \\
\text { wineries }\end{array}$ & $\begin{array}{l}\text { Small and } \\
\text { family } \\
\text { wineries }\end{array}$ & Other & $\begin{array}{l}\text { Total } \\
\text { sector }\end{array}$ & $\begin{array}{l}\text { Sig. } \\
\text { between } \\
\text { groups }\end{array}$ \\
\hline \multirow{12}{*}{$\begin{array}{l}\text { Internal } \\
\text { factors }\end{array}$} & Winery equipment and facilities & 24.25 & 66.00 & 36.80 & 54.36 & 48.33 & 48.91 & 0.047 \\
\hline & Wine know-how and technology & 38.25 & 80.40 & 53.90 & 66.88 & 51.67 & 62.10 & 0.171 \\
\hline & Wine basket variety & 8.75 & 39.00 & 18.00 & 19.52 & 21.00 & 20.45 & 0.052 \\
\hline & Wine region and terroir & 15.50 & 31.20 & 18.60 & 33.50 & 17.70 & 27.55 & 0.621 \\
\hline & Wine standard & 5.50 & 10.20 & 10.70 & 11.68 & 31.33 & 12.04 & 0.093 \\
\hline & Wine pricing & 3.50 & 27.60 & 29.90 & 14.80 & 23.33 & 18.96 & 0.020 \\
\hline & Visitor center facilities & 26.00 & 38.60 & 26.10 & 27.84 & 39.33 & 29.19 & 0.680 \\
\hline & Visitor center quality of service & 26.25 & 47.80 & 40.50 & 35.60 & 15.00 & 35.83 & 0.354 \\
\hline & Wine tourism product variety & 20.00 & 19.00 & 15.50 & 17.00 & 19.33 & 17.29 & 0.981 \\
\hline & Availability of database & 1.50 & 3.60 & 8.60 & 3.76 & 3.33 & 4.55 & 0.019 \\
\hline & Wine culture & 5.00 & 28.40 & 35.60 & 29.08 & 26.67 & 28.19 & 0.052 \\
\hline & Total & 174.50 & 391.80 & 294.20 & 314.02 & 297.02 & 305.06 & 0.067 \\
\hline 300 & Internal vector intensity & $(125.50)$ & 91.80 & $(5.80)$ & 14.02 & $(2.98)$ & 5.06 & \\
\hline \multirow{12}{*}{$\begin{array}{l}\text { External } \\
\text { factors }\end{array}$} & Wine market demand & 1.00 & 61.60 & 39.60 & 42.28 & 30.00 & 39.47 & 0.057 \\
\hline & Ministry of Tourism policy & 38.85 & 22.20 & 26.00 & 28.12 & 10.67 & 25.68 & 0.073 \\
\hline & Ministry of Agriculture policy & 63.25 & 22.40 & 18.60 & 22.48 & 20.00 & 24.96 & 0.020 \\
\hline & VWB policy & 55.05 & 33.20 & 14.40 & 20.28 & 22.67 & 22.02 & 0.084 \\
\hline & Ministry of Industry and Trade & 12.00 & 30.00 & 13.40 & 15.56 & 18.33 & 16.51 & 0.044 \\
\hline & Investors’ willingness & 37.25 & 40.20 & 38.60 & 23.36 & 30.00 & 30.00 & 0.511 \\
\hline & Economy and security & 8.00 & 23.20 & 20.30 & 17.60 & 16.70 & 17.89 & 0.616 \\
\hline & Availability of financial support & 7.75 & 35.20 & 20.70 & 17.80 & 18.33 & 19.44 & 0.213 \\
\hline & Wine trail and tourism development & 72.75 & 46.40 & 59.50 & 61.44 & 82.00 & 61.70 & 0.709 \\
\hline & HR availability & 15.25 & 14.40 & 17.90 & 16.92 & 15.67 & 16.64 & 0.981 \\
\hline & Regulations and standards & 1.25 & 12.40 & 19.70 & 22.64 & 8.33 & 18.19 & 0.056 \\
\hline & Total & 312.40 & 341.20 & 288.70 & 288.48 & 272.70 & 292.50 & 0.180 \\
\hline 300 & External vector intensity & 12.40 & 41.20 & $(11.30)$ & $(11.52)$ & $(27.30)$ & $(7.50)$ & \\
\hline
\end{tabular}

Regarding the internal vector intensity, "winery equipment and facilities" (48.91) and "wine know-how and technology" (62.10) are the core contributors to the strength of the sector, particularly the big wineries position (66.00 and 80.40, respectively), but significantly ( $p=0.047$ ) opposed to the government and VWB position (24.25 and 38.25, respectively). "Visitor center facilities" (29.19) and "visitor center quality of service" (35.83) are the second most important contributors, particularly for big wineries (38.60 and 47.80, respectively) which operate established visitor centers. Mid and small and family wineries score these factors lower and feel that much more should be done to strengthen current facilities and services provided at the wineries (facilities, training, etc.). "Wine region and terroir" (27.55) and "wine culture" (28.19) are ranked the third important factors contributing to the strength of the wine sector. A significant difference $(p=0.052)$ was found between government and VWB position and other groups regarding the "wine culture" factor. It was indicated by all stakeholders that a big emphasis should be put on developing a "wine region" (terroir) and "wine trails", as well as wine culture awareness program. This will differentiate and enhance wine regions and wine tourism, the domestic market, and even more, for export purposes. This is followed by "wine tourism product variety" (17.29) with no significant difference among the groups. The overall view is that currently, this factor does not contribute much and therefore there is a need to extend the variety of wine tourism products such as festivals and 
events, restaurants, $\mathrm{B} \& \mathrm{~B}$, and other complementary tourism activities in the wine region. The groups feel that "availability of database" (4.55) is the least significant contributing factor to the strength of the sector and that at the moment, it is not the top priority. Contribution of the "wine basket variety" factor (20.45) is ranked moderately: for big wineries (39.00), the basket contributes more strength than for mid and small and family wineries (18.00 and 19.52, respectively), with a significant difference from the government and VWB position (8.75, $p=0.052)$. Concerning external vector intensity, "wine trail and tourism development" factor provides the biggest opportunity (61.70) with no significant difference among the groups. Small and family wineries perceive it higher (61.44) than mid wineries (59.50) and big wineries (46.40), mainly because that they rely and depend much more on cellar door sales and the wine tourism system. Next comes the "wine market demand" factor (39.47) headed by the big wineries group (61.60), but with a significant difference $(p=0.057)$ from the government and VWB (1.00) and "other" (30.00). An interesting finding is that government and VWB group members perceive their own policy contribution as a high "opportunity" (38.85, 63.25, and 55.05, respectively) for the sector, contrary to all other wineries groups which rate this significantly below $30(p=0.073, p=0.020$, and $p=0.084$ ). The "investors" willingness" (30.00) and "availability of financial support” factors (19.44) reflect a low opportunity level for wine tourism development. Government and VWB as well as big wineries and "other” groups rank willingness higher than mid and small and family wineries, while all are of the opinion that current financial support is not much sufficiently available, particularly government and VWB (7.75), compared to big wineries (35.20) which can get financial support easier than mid and small and family wineries. "Regulations and standards” (18.19), “economy and security” (17.89), "HR availability” (16.64), and "Ministry of Industry and Trade" (16.51) are the factors that provide the least opportunity to the wine sector. The "leading strategy" is determined as the equivalent vector of the calculated relative intensity vector of the internal vectors $\mathrm{S}$ and $\mathrm{W}$ and the external factors $\mathrm{O}$ and $\mathrm{T}$, and summarized for the various groups as shown in Table 5.

Table 5

“Leading Strategy" Position for Wine Stakeholder Groups

\begin{tabular}{lclllccc}
\hline & $\begin{array}{l}\text { Government } \\
\text { and VWB }\end{array}$ & $\begin{array}{l}\text { Big } \\
\text { wineries }\end{array}$ & $\begin{array}{l}\text { Mid } \\
\text { wineries }\end{array}$ & $\begin{array}{l}\text { Small and } \\
\text { family } \\
\text { wineries }\end{array}$ & Other & $\begin{array}{l}\text { Total } \\
\text { sector }\end{array}$ & $\begin{array}{l}\text { Sig. between } \\
\text { groups }\end{array}$ \\
\hline Internal vector intensity & -125.50 & 91.80 & -5.80 & 14.02 & -2.98 & 5.06 & 0.047 \\
$\begin{array}{l}\text { External vector intensity } \\
\text { Leading strategy }\end{array}$ & 12.40 & 41.20 & -11.30 & -11.52 & -27.30 & -7.50 & 0.073 \\
\hline
\end{tabular}

The "leading strategy" of the wine sector is perceived as response. The big winery group determines growth as the "leading strategy", compared to response of the other wineries groups, leverage by the government and VWB group, and survival for the "other" group. Resulted leading strategy position of each group is shown in Figure 1.

The small population size of about 250-300 Israeli wineries in total and the reluctance of some wineries to participate affect the sample size of valid questionnaires (56) and partly the significance in difference of strategy factors between some groups. The recommended sample size for significance $(p<0.05)$ was calculated by the $\mathrm{G}^{*}$ Power 3 model software, based on the results of the $t$-test, and the difference between the average amount of internal and external factors that determines the "leading strategy". In the case where the sample size of big, mid, and small and family wineries will be equal $\left(n_{1}=n_{2}=n_{3}\right)$, the required calculated sample size $(p<0.05,0.95)$ is 95 for each population group. Practically, this is not achievable since to such because the number of big and mid wineries is smaller than the recommended sample size. 


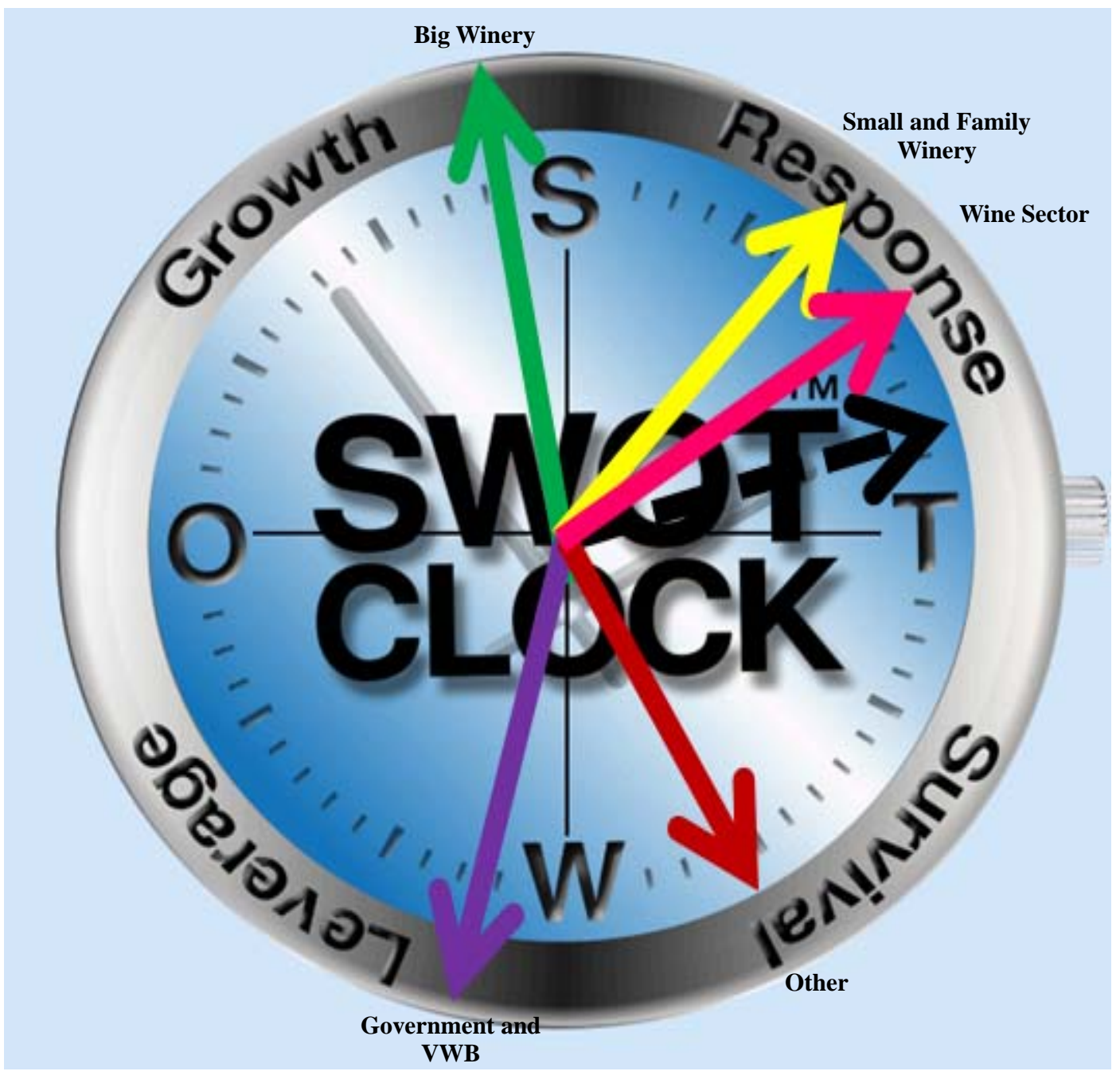

Figure 1. "Leading strategy" of wine sector stakeholder groups.

\section{Analysis of Empirical Data}

The SWOTCLOCK ${ }^{\mathrm{TM}}$ model (Tirosh, 2010; 2013) assumes a validation and compatibility between the developmental stages of the TALC model (Butler, 2006a; 2006b) and therefore, the second research question concerns the compliance between the models. An official database for the wine industry and tourism is almost nonexistence, so the analysis is based on VWB empirical database which tracks vine plantation and it can be used as a yardstick reflecting the development trend of the sector. Results of the empirical analysis correspond to the characteristics of the TALC model and thus support, confirm, and validate the basic assumptions of compatibility to the SWOTCLOCK ${ }^{\mathrm{TM}}$ model, as shown in Figure 2.

The actual new vine plantation has high matching polynomials $\left(R^{2}=0.907\right)$ fit. This behavior shows a trend change in the leading strategy since 2002, from leverage in 2002 to growth in the period of 2004-2009 and turning to response from 2010 until today. That is very similar to the sequence of behavior stages of the TALC model, where the "exploration" stage is followed by "growth" and then by "stagnation". Results of the empirical analysis correspond to the characteristics of the TALC model and thus support and confirm the basic assumptions of compatibility to the SWOTCLOCK ${ }^{\mathrm{TM}}$ model. 


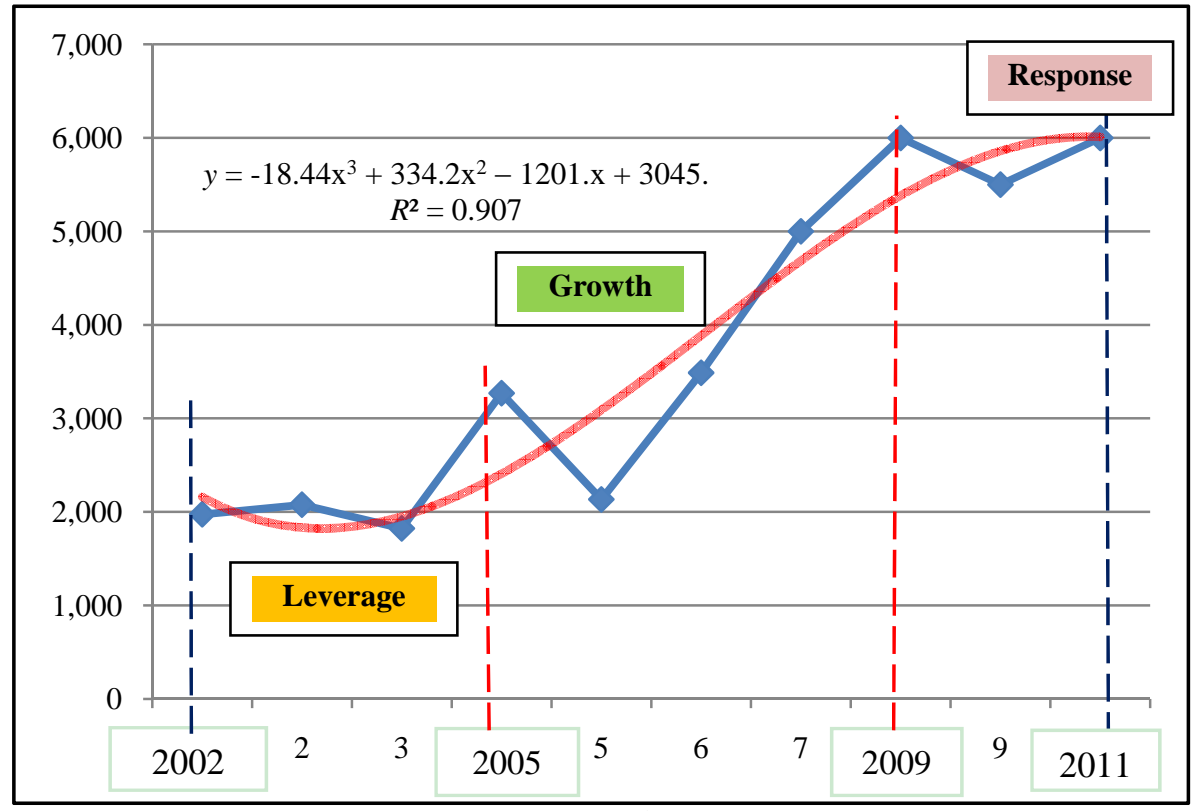

Figure 2. New vineyard plantations ('000 $\left.\mathrm{m}^{2}\right)$. Source: VWB empirical database.

Big wineries distribute most of their production through wholesale networks. Therefore, the assumption is that direct wine sales in small and family wineries are proportionally higher than in mid and big wineries. Empirical data of the proportion (\%) of direct wine sales at the winery were collated from the questionnaires and the interviews. A regression analysis shows the relationship between the direct volume of sales (VOS) (\%) at the cellar door and visitor center out of the total VOS of the winery, as shown in Figure 3.

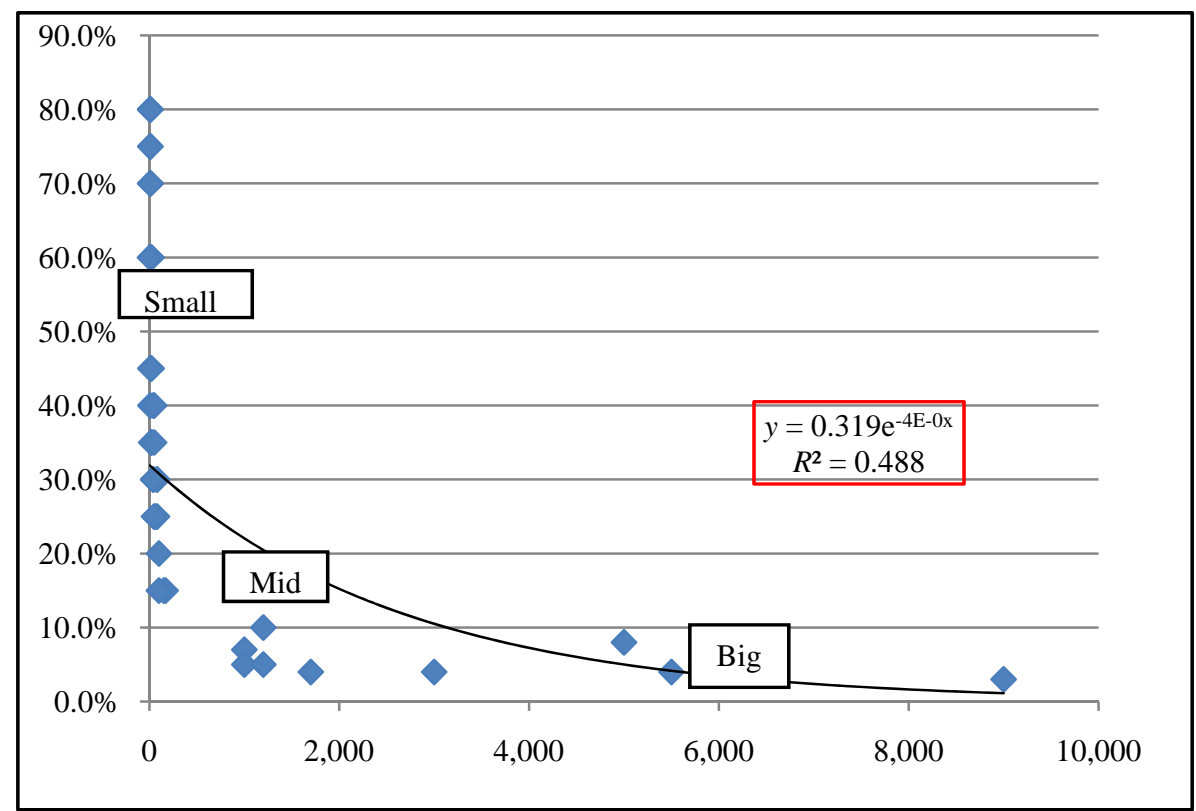

Figure 3. Direct VOS (\%) at wineries vs. volume of production (,000 bottles). Source: research primary collated data.

From the resulting calculated nonlinear regression formula and the correlation coefficient $\left(R^{2}=0.488\right)$, it is clear that small and family wineries sell most of their wine production on site (VOS $>35 \%$ ) compared to the mid wineries (VOS $<15 \%$ ) and big wineries, where this takes place at the visitor center (VOS $<8 \%$ ). The conclusion 
is that small and family wineries are much more directly related to wine visitors and that therefore, wine culture and wine tourism are key issues for them more than for mid and big wineries. This correlates also to the "level of importance" perception of the "wine culture" factor (12.9\%) compared to the big wineries group (8.8\%).

\section{Summary and Conclusions}

Over the last two decades, the wine and wine tourism in Israel are experiencing a rapid growth, regarding production and marketing. That is characteristically the behavior of a fast growing and emerging young industry which is facing the strategic dilemma of how to determine the best way to move to sustain and expand growth. The research questions focus on identifying the strategic positions of various stakeholder groups in the wine sector. Two typologies, SWOTCLOCK ${ }^{\mathrm{TM}}$ and the TALC models, approached the dilemma from different angles and the results of the study show a compatibility and validity between them. Stakeholder groups indicate a different "leading strategy" for the wine industry and tourism. Big wineries feel that currently, the sector operates a growth strategy, compared to the response strategy indicated by mid and small and family wineries, the leverage strategy indicated by the government and VWB, and the survival strategy of the "other" group. The overall equivalent "leading strategy" of the sector is response. Particularly, a significant difference and gaps were found between the government and VWB position and the "other" group. Currently, most wineries operate visitor centers, “cellar door”, and wine tasting activities, but other components of wine tourism such as wine trail, terroir, and region tourism network (Bras et al., 2010) are only at the early stage of development. This pattern of behavior indicates that the wine sector is reaching a deflection period from "stability and stagnation" to "rejuvenation, involvement, and development", according to the TALC model, and from "response" to "leverage", according to the SWOTCLOCK ${ }^{\mathrm{TM}}$ model. All groups indicate that the development of wine regions and wine trail is the appropriate step to boost wine culture and wine tourism, which can bring about an increase in wine consumption. Gaps found among the groups could be closed if government and VWB were to play a bigger and leading role in promoting wine awareness, culture, and education, through intensive advertising schemes, developing wine routes and trails and wine region (terroir), in collaboration with local authorities and wineries. Findings ranked "wine culture" and "wine trail and tourism development" as major factors together with the "winery equipment and facilities" and "wine know-how" factors, reflecting the strengths of the sector. Since mid and small and family wineries do not have enough marketing and economic power for developing wine regions (terroir) and trails, government and VWB and local and regional authorities should take the leading role in this area. Although big wineries market is not directly related to wine tourism activities, as it is for mid and particularly small and family wineries, they should participate given the benefits they can gain from the enhancement of wine culture, education, and exposure to wine consumption. Wine tourism in Israel is facing two major regulatory barriers: the restriction on constructing and operating winery (industrial entity) at a vineyard site (agricultural entity); and the Jewish religious restriction stipulating that "Kosher" winery must be closed on Saturdays and Jewish holy days. The negative effect is that wine visitors and tourists cannot maximize their vineyard and winery visit experience and that some potential wine marketing segments do not have access to wineries' visit during the peak time of weekends and holidays. The research findings and recommendations set a big challenge to the wine industry and wine tourism in Israel in order for it to meet the overall objectives of not only increasing wine consumption, attracting more domestic and incoming wine and other tourists, but also enhancing and expanding the export of Israeli wines through the establishment and differentiation of wine regions (terroir), branding and producing top-quality unique wines. 


\section{References}

Bernroider, E. (2002). Factors in SWOT analysis applied to micro, small to medium, and large software enterprises: An Austria study. European Management Journal, 20(5), 562-573.

Bras, J. M., Costa, C., \& Buhalis, D. (2010). Network analysis and wine routes: The case of the Bairrada wine route. The Service Industries Journal, 30(10), 1621-1641.

Butler, R. W. (2006a). The tourism area life cycle: Applications and modifications (Vol. 1). Clevedon: Channel View Publications.

Butler, R. W. (2006b). The tourism area life cycle: Conceptual and theoretical issues (Vol. 2). Clevedon: Channel View Publications.

Cambourne, B., Macionis, N., Hall, M. C., \& Sharples, L. (2002). The future of wine tourism. In M. C. Hall, L. Sharples, B. Cambourne, \& N. Macionis (Eds.), Wine tourism around the world: Development, management, and markets (pp. 297-320). Oxford: Butterworth-Heinemann.

Carlsen, J. (2004). A review of global wine tourism research. Journal of Wine Research, 15(1), 5-13.

Carlsen, J., \& Charters, S. (Eds.). (2006). Global wine tourism: Research, management, and marketing. Cambridge, MA: CAB International.

Charters, S., \& Ali-Knight, J. (2002). Who is the wine tourist? Tourism Management, 23(3), 311-319.

Cohen, E., \& Ben-Nun, L. (2009). The important dimensions of wine tourism experience from potential visitors’ perception. Tourism and Hospitality Research, 9(1), 20-31.

Correira, L., \& Ascencao, P. (2006). Wine tourism in Portugal: The Bairrada wine route. In J. Carlsen \& S. Charters (Eds.), Global wine tourism: Research, management, and marketing (pp. 242-254). Cambridge, MA: CAB International.

Dowling, R., \& Getz, D. (2001). Wine tourism futures. In B. Faulkner, E. Laws, \& G. Moscardo (Eds.), Tourism in the 21st century: Lessons from experience (pp. 49-66). London: Continuum.

Fraser, R., \& Alonso, A. (2006). Do tourism and wine always fit together? A consideration of business motivations. In J. Carlsen \& S. Charters (Eds.), Global wine tourism: Research, management, and marketing (pp. 19-26). Cambridge, MA: CAB International.

Getz, D. (2000). Explore wine tourism: Management, development, and destinations. New York, NY: Cognizant Communication Corporation.

Getz, D. (2002). Wine tourism in Canada: Development, issues, and prospects. In C. Cullen, G. Pickering, \& R. Phillips (Eds.), Bacchus to the future. Proceedings of the Inaugural Brock University Wine Conference (pp. 331-356), St. Catharines Ontario, Canada.

Getz, D., \& Brown, G. (2006). Critical success factors for wine industry: A demand analysis. Tourism Management, 27(1), 146-158.

Getz, D., Carlsen, J., Brown, G., \& Havitz, M. (2007). Wine tourism and consumers. In A. G. Woodside, \& D. Martin (Eds.), Tourism management: Analysis, behavior, and strategy (pp. 245-267). UK: CABI.

Getz, D., Dowling, R., Carlsen, J., \& Anderson, D. (1999). Critical success factors for wine tourism. International Journal of Wine Marketing, 11(3), 20-43.

Hall, C. M., Sharples, L., Cambourne, B., \& Macionis, N. (2000). Wine tourism around the world: Development, management, and markets (1st ed., pp. 150-176). Oxford, UK: Elsevier Science.

Harkabi, E. (2012). Wine vineyard: 2012 state of the art. Planter's Newsletter, 66, 22-23 (in Hebrew).

Mora, P. (2007). Key success factors in today's wine sector. International Journal of Case Method Research and Application, 19(1), 25-33.

Robinson, J. (2006). The Oxford companion to wine (3rd ed.). Oxford: Oxford University Press.

Sacks, E., \& Goldfisher, Y. (2011). The wine route of Israel. Tel Aviv: Coordinata Publishers.

Sanders, D. (2004). Wine tourism and regional development: A case study of the Margaret wine region, Western Australia. In J. Carlsen \& S. Charters (Eds.), International wine tourism research. Proceedings of the International Wine Tourism Conference, Margaret River, Western Australia. Perth, Australia: Vineyard Publications.

Shor, N., \& Mansfeld, Y. (2009). Between wine consumption and wine tourism: Consumer and spatial behavior of Israeli wine tourists. Tourism Original Scientific Paper, 57(4), 381-403.

Skinner, A. M. (2002). Napa Valley, California: A model of wine region development. In M. C. Hall, L. Sharples, B. Cambroune, \& N. Macionis (Eds.), Wine tourism around the world: Development, management, and markets (pp. 283-296). Oxford: Butterworth-Heinemann. 
Sparks, B., \& Malady, J. (2004). Developing wine and food regions: Product, people, and perseverance. In J. Carlsen \& S. Charters (Eds.), International wine tourism research. Proceedings of the International Wine Tourism Conference, Margaret River, Western Australia. Perth, Australia: Vineyard Publications.

Tirosh, N. (2010). The SWOT CLOCK behavior. Proceedings of the 3rd Annual EuroMed Conference (pp. 943-962), Nicosia.

Tirosh, N. (2013). Mutual strategy relationship of Eilat vs. Aqaba as tourism destinations. Journal of Global Business Advancement, 6(1), 59-74.

Winemakers’ Federation of Australia. (1988). National wine tourism strategy WFA. Adelaide, Australia. 